\title{
Hereditary hemochromatosis: An opportunity for gene therapy
}

\author{
FERNANDO EZQUER ${ }^{1,2,4}$, MARCO T NÚÑEZ ${ }^{1,2}$, ALEJANDRO ROJAS $^{1,2}$, \\ JUAN ASENJO ${ }^{1,3}$ and YEDY ISRAEL ${ }^{1,4,5}$
}

\begin{abstract}
${ }^{1}$ Millennium Institute for Advanced Studies in Cell Biology and Biotechnology; ${ }^{2}$ Department of Biology, Faculty of Sciences, ${ }^{3}$ Department of Chemical Engineering, Centre for Biochemical Engineering and Biotechnology, ${ }^{4}$ Laboratory of Gene Therapy, Department of Pharmacological and Toxicological Chemistry, Faculty of Chemical and Pharmaceutical Sciences, Universidad de Chile, Santiago, Chile and ${ }^{5}$ Department of Pathology, Anatomy and Cell Biology, Thomas Jefferson University, Philadelphia, Pennsylvania, USA
\end{abstract}

\begin{abstract}
Levels of body iron should be tightly controlled to prevent the formation of oxygen radicals, lipoperoxidation, genotoxicity, and the production of cytotoxic cytokines, which result in damage to a number of organs. Enterocytes in the intestinal villae are involved in the apical uptake of iron from the intestinal lumen; iron is further exported from the cells into the circulation. The apical divalent metal transporter-1 (DMT1) transports ferrous iron from the lumen into the cells, while the basolateral transporter ferroportin extrudes iron from the enterocytes into the circulation. Patients with hereditary hemochromatosis display an accelerated transepithelial uptake of iron, which leads to body iron accumulation that results in cirrhosis, hepatocellular carcinoma, pancreatitis, and cardiomyopathy. Hereditary hemochromatosis, a recessive genetic condition, is the most prevalent genetic disease in Caucasians, with a prevalence of one in 300 subjects. The majority of patients with hereditary hemochromatosis display mutations in the gene coding for HFE, a protein that normally acts as an inhibitor of transepithelial iron transport. We discuss the different control points in the homeostasis of iron and the different mutations that exist in patients with hereditary hemochromatosis. These control sites may be influenced by gene therapeutic approaches; one general therapy for hemochromatosis of different etiologies is the inhibition of DMT1 synthesis by antisense-generating genes, which has been shown to markedly inhibit apical iron uptake by intestinal epithelial cells. We further discuss the most promising strategies to develop gene vectors and deliver them into enterocytes.
\end{abstract}

Key terms: iron, intestine, hemochromatosis, gene therapy, HFE, DMT1, cirrhosis

Iron is a vital element for all mammalian cells. The electronic structure of its two oxidation states $\left(\mathrm{Fe}^{+2}\right.$ and $\left.\mathrm{Fe}^{+3}\right)$ renders it the most versatile cofactor in biological redox reactions. However, in excess, unbound iron is highly toxic, due to its participation in the generation of free radicals and reactive oxygen species. These molecules induce peroxidation of membrane lipids and of DNA leading to cellular injury, ultimately resulting in severe damage of different organs. For this reason, in health, functional iron content is maintained within narrow limits to provide sufficient iron for the synthesis of essential ferroproteins, thus avoiding the toxic effects seen in iron overload (Andrews, 1999). Since there are no effective physiological mechanisms for iron excretion, iron homeostasis is regulated solely at the intestinal absorption level.

\section{INTESTINAL IRON ABSORPTION}

The mechanisms of intestinal iron absorption are depicted in figure 1. Nearly all the absorption of dietary iron occurs in

Corresponding Author: Dr. Yedy Israel, Laboratory of Gene Therapy, Department of Pharmacological and Toxicological Chemistry, Faculty of Chemical and Pharmaceutical Sciences, Universidad de Chile, Olivos 1007, Santiago, Chile, Tel.: (56-2) 978-2944, Fax: (56-2) 737-7291, E-mail: yedy.israel@uchile.cl 
the duodenum, where specific carrier molecules are synthesized by the villous enterocyte. Dietary iron may be taken up either as free iron or as heme iron (Andrews, 1999). Free iron is largely present in the diet as oxidized ferric ion $\left(\mathrm{Fe}^{+3}\right)$, which being insoluble is hardly available to be incorporated into the absorptive enterocyte. Thus, prior to absorption ferric iron is reduced to the more soluble ferrous form $\left(\mathrm{Fe}^{+2}\right)$ by the reductase Dcytb, located in the luminal surface of the duodenal enterocyte (McKie et al., 2001).

After reduction, iron is transported across the brush border membrane (apical membrane) by the divalent metal transporter DMT-1 (Fleming et al., 1997; Gunshin et al., 1997), which also can transport a number of other divalent metals such us $\mathrm{Cu}^{+2}$ (Arrendondo et al., 2003) and $\mathrm{Co}^{+2}$ (Forbes and Gros, 2003). Transporter DMT1 also has been involved in the transport of $\mathrm{Cd}^{+2}$ and $\mathrm{Mn}^{+2}$ (Olivi et al., 2001; Elisma and Jumarie, 2001; Tallkvist et al., 2001).

Mutations in DMT-1 are responsible for defects in intestinal iron uptake both in the mouse model of microcytic anemia (Fleming et al., 1997) and in Belgrade rats (Fleming et al., 1998). Loss of DMT-1 function in those animals results in very low rates of absorption of dietary iron and a profound microcytic anemia, indicating that DMT-1 is the main transporter that incorporates iron into intestinal epithelial cells. Uptake of heme iron occurs by an unidentified transporter not related to DMT-1 (Lynch et al., 1989; Wolf et al., 1994).

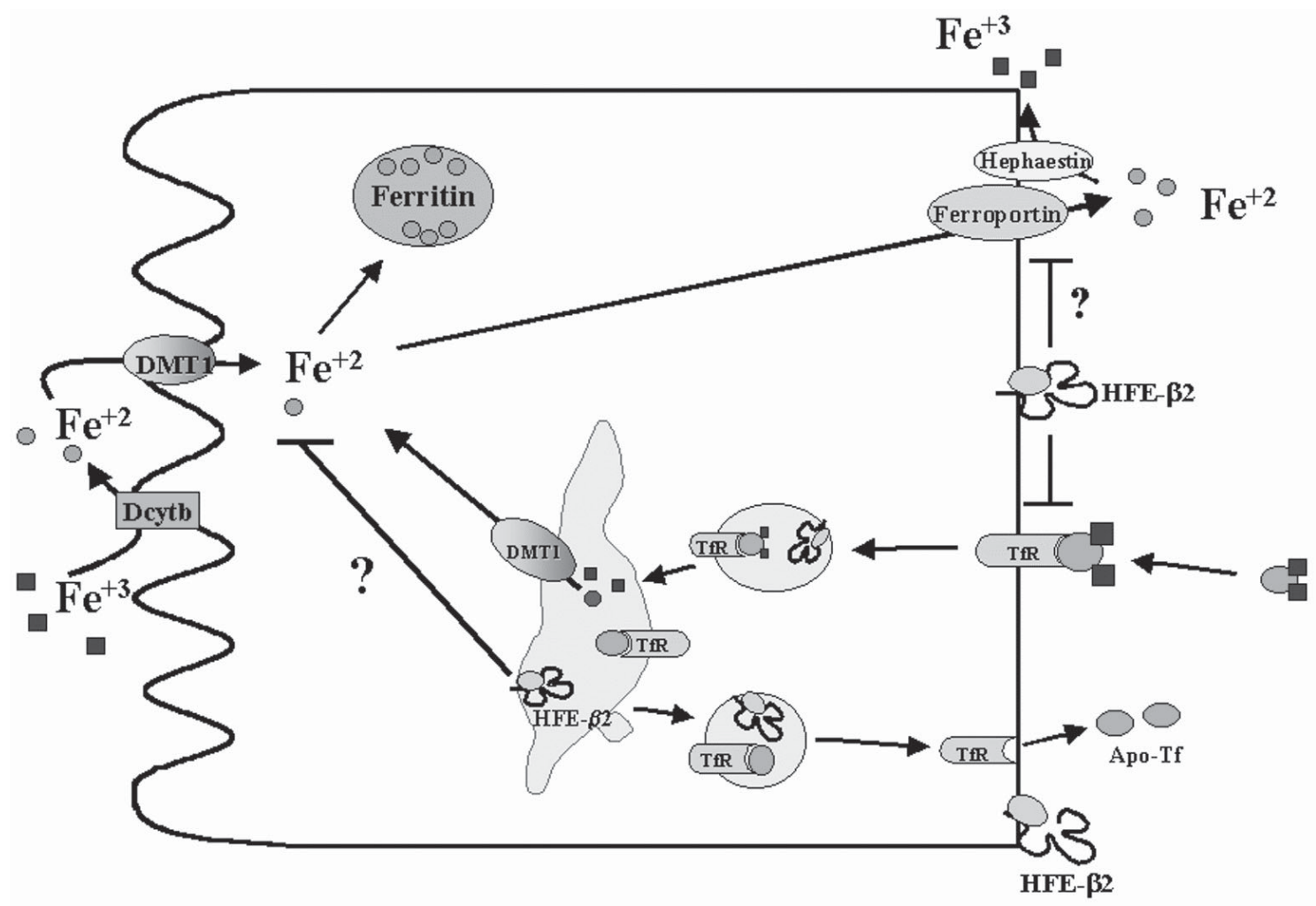

Figure 1: Proposed model of ionic iron absorption by the enterocyte: Ferric iron is reduced in the intestinal lumen by membrane reductase DcytB. Ferrous iron is transported across the plasma membrane by the divalent metal transporter DMT-1. Within cells, iron is stored as ferritin or exported across the basolateral surface by the iron transporter ferroportin. Exported iron is converted to ferric iron by the membrane oxidase hephaestin and bound to transferrin for distribution to tissues. Note that the enterocyte also can take up iron into the endosomes via the transferrin receptor. The proposed mechanisms by which HFE acts are discussed in the text. 
Iron entering the absorptive enterocyte is stored either within the cell bound to ferritin for the short life of the enterocyte or it is transferred to the circulation by the action of the iron transporter ferroportin-1 located in the basolateral membrane (Donovan et al., 2000). Ferrous iron is reoxidized to $\mathrm{Fe}^{+3}$ before it binds to circulating transferrin. This oxidization is likely catalyzed by the oxidase hephaestin (Vulpe et al., 1999). A defective hephaestin is associated with the sex-linked anemia (sla) mouse (Vulpe et al., 1999). Subsequently, the absorbed iron is bound to transferrin and transported via the portal system to the liver, which is the major site of iron storage associated to ferritin and hemosiderin (Kawabata et al., 1999; Fleming et al., 2000).

\section{REGULATION OF INTESTINAL IRON ABSORPTION}

From the above, it follows that iron homeostasis depends on the coordinated function of numerous genes. Intestinal iron absorption in humans is regulated by body iron stores, which prevent iron overload after ensuring that iron needs are reached (Fleming et al., 2004). One important component of this regulation system is hepcidin, a peptide of 20-25 amino acids that has multiple disulfide bonds. Hepcidin is synthesized from a larger precursor and secreted by the liver in response to both inflammatory stimuli (often linked to oxidative stress) and iron overload (Krause et al., 2000; Park et al., 2001; Pigeon et al., 2001). Studies in transgenic mice indicate that hepcidin has a key role in downregulating enterocyte iron absorption and in inhibiting the release of this metal ion from macrophages (Ganz, 2003). Deletion of the hepcidin gene results in massive iron loading of the liver (Nicolas et al., 2001), whereas transgenic overexpression of this gene leads to severe anemia (Nicolas et al., 2002). Another iron regulatory mechanism acts at the enterocyte level by a diminished interaction of intracellular iron-loaded regulatory proteins (IRPs) with specific structural elements in mRNA transcripts called iron-regulatory elements (IREs)
(Rouault et al., 1997). The binding of IRPs to IREs increases under cellular iron depletion conditions. This has been proposed to increase both the stability and abundance of mRNA transcripts with IRE elements in the 3 ' untranslated region (UTR), including the mRNA for transferrin receptor-1 and probably one of the DMT-1 isoforms (Hubert and Hentze, 2002). Conversely, the binding of IRPs to IREs in the 5' UTR of mRNA blocks its translation, which occurs in transcripts encoding the ferritin $\mathrm{H}$ and $\mathrm{L}$ chains. While under conditions of iron accumulation TfR 1 translation is downregulated and ferritin levels are upregulated, the case for the regulation of the iron transporters DMT-1 and ferroportin seem to be different. Two of the isoforms of DMT-1 have an IRE in the 3' UTR, whereas ferroportin has an IRE in the 5' UTR (Hubert and Hentze, 2002; McKie et al., 2000) Nevertheless regulation of DMT-1 expression seem to be mostly IRE independent (Hubert and Hentze, 2002; McKie et al., 2000). The regulation of ferroportin expression is unknown but seems to be cell specific (McKie et al., 2000; Aguirre et al., 2005).

\section{HEREDITARY HEMOCHROMATOSIS}

Alterations in iron homeostasis lead to frequent pathological disorders in humans. One of these is hereditary hemochromatosis $(\mathrm{HH})$, an autosomal recessive condition in which intestinal iron absorption is greatly elevated (Brittenham et al., 2000). About one million individuals in the U.S. are affected by this disease (Levy et al., 1999), exceeding the prevalence of cystic fibrosis and muscular dystrophy combined (Bacon et al., 1999).

The disease is characterized by overabsorption of dietary iron and an accelerated recycling of this metal by macrophages despite adequate iron stores.

The clinical features of the disease arise as result of decades of progressive accumulation of iron in parenchymal cells of the liver, pancreas, and heart. In the most advanced form, the disease is manifested as cirrhosis, hepatocellular 
cancer, diabetes mellitus, hypogonadism, cardiomyopathy, arthritis, and skin pigmentation. In 1996, Feder and colleagues identified the HFE gene, the mutation of which is responsible for over $80 \%$ of hereditary hemochromatosis (Feder et al., 1996). The HFE gene codes for a novel major histocompatibility complex MHC class I-like molecule. This protein binds to $\beta 2$-microglobulin, an event necessary for its targeting to the plasma membrane (Waheed et al., 1997; Feder et al., 1998; Gross et al., 1998).

Most $\mathrm{HH}$ patients are homozygous for a point mutation in the HFE gene. The mutation that was initially described for HFE in association with $\mathrm{HH}$ is a single base change in exon 4 that results in the substitution of a tyrosine for cysteine at amino acid 282 (C282Y) of the unprocessed HFE protein (Feder et al., 1996). This mutation leads to the disruption of a disulfide bond needed to form the loop that interacts with $\beta 2$-microglobulin. As a result, the $\mathrm{C} 282 \mathrm{Y}$ mutant $\mathrm{HFE}$ protein is retained in the endoplasmic reticulum and fails to undergo late Golgi processing, reducing its abundance on the cell surface (Feder et al., 1997; Waheed et al., 1997). A second mutation in the HFE gene, in which an aspartic acid moiety replaces histidine at position 63 (H63D) of the HFE protein, also has been reported (Gochee et al., 2002). The phenotype of duodenal cells in $\mathrm{HH}$ is similar to that of iron deficiency, as seen by low levels of ferritin mRNA and increased levels of DMT-1, ferroportin and transferrin receptor I (Fleming et al., 1997; Gunshin et al., 1997; McKie et al., 2000; Zoller et al., 2003), indicating that a key factor in the regulation of iron absorption is altered. Histochemical techniques have localized HFE to a number of different cell types, including Kupffer cells (Bastin et al., 1998), the gastrointestinal tract (Parkkila et al., 1997), placenta (Parkkila et al., 1997), macrophages and crypt cells of the small intestine (Griffiths et al., 2003).

The precise mechanisms by which HFE inhibits iron absorption by the enterocyte are not yet clear, and some controversy exists with regard to the role of HFE in the control of iron absorption in the gut.
Normal HFE protein has been shown to inhibit both apical iron uptake and basolateral iron transfer in polarized intestinal cells (Arredondo et al., 2001; Davies and Enns, 2004). Inhibition of apical iron uptake was noted despite an increment in DMT-1 protein in HFEtransfected Caco-2 cells (Arredondo et al., 2001), whereas HFE transfection induced decreased levels of hephaestin mRNA (Davies and Enns, 2004). These results raise the possibility that HFE may be coordinately inhibiting the activity of both the iron import and iron export machinery in intestinal cells. Other mechanisms, such as the normal development of crypt cells into high DMT-1 enterocytes, also have been proposed (Bacon et al., 1999). Independently of the mechanism of action of the HFE protein, the experimental data suggest that the loss of HFE function results in increased activity of some of the proteins involved in intestinal iron uptake, which results in an increased incorporation of dietary iron.

The cloning of the HFE gene paved the way for the identification of non HFErelated forms of $\mathrm{HH}$ and the recognition of mutations in a number of other genes implicated in iron metabolism. Examples of these non HFE-related forms of hemochromatosis are juvenile hemochromatosis (or $\mathrm{HH}$ type II), which is an autosomal recessive disease due to mutations in the hepcidin gene or in the gene for hemojuvelin, a recently identified protein implicated in iron regulation (Roetto et al., 2003; Papanikolaou et al., 2004). Juvenile hemochromatosis is a more severe form of iron-loading disorder than HFE-related hemochromatosis, being characterized by an early onset, usually before the age of 30 . Hereditary hemochromatosis type III is a rare form of $\mathrm{HH}$ caused by a mutation in the gene that codes for transferrin receptor II (Camaschella et al., 2000). The clinical phenotype is similar to HFE-related hemochromatosis, with iron deposition in the liver. Finally, hemochromatosis type IV is an autosomal dominant form of iron overload associated with mutations in the gene that codes for the iron exporter ferroportin (Montosi et al., 2001; Njajou et al., 2001). 
The basic features shared by all of these iron overload disorders indicate that they are genetic variants of the same syndrome.

\section{TREATMENT OF HEREDITARY HEMOCHROMATOSIS}

Hereditary hemochromasosis $(\mathrm{HH})$ is usually diagnosed after the development of symptoms in the fourth to sixth decades of life, when patients have significant iron overload. If not treated, $\mathrm{HH}$ invariably progresses and is ultimately fatal. The only accepted treatment for this disease stems from medieval times and is the performing of periodic bleeding (phlebotomy). At present, initially one or two units of blood (500-1000 ml) each containing 200-250 mg of iron are removed weekly until serum ferritin levels are reduced below $50 \mathrm{ng} / \mathrm{ml}$ and transferrin saturation drops to a value below $30 \%$ (requiring 2 to 3 years). Less aggressive bleeding, but life-long maintenance therapy, is then mandatory to keep the transferrin saturation value below $50 \%$ and the serum ferritin levels below 100 $\mathrm{ng} / \mathrm{ml}$ (Niedderau et al., 1985; Wojcik et al., 2002). However, the rate of iron reloading is highly variable (Adams et al., 1991). The transferrin saturation remains elevated in many treated patients and does not normalize unless the patients become iron deficient, greatly affecting the quality of life.

\section{GENE THERAPY APPROACHES FOR THE}

TREATMENT OF HEREDITARY HEMOCHROMATOSIS

Under conditions of iron overload, bile iron excretion accounts for only a minor fraction of total iron (Oates et al., 2000), and thus, it cannot reduce body iron levels. Therefore, the primary focus of whole body iron homeostasis is the control of intestinal iron absorption. Because of the accessibility of intestinal stem cells to gene therapy vectors, $\mathrm{HH}$ constitutes an optimal target for gene therapy.

There are several strategies to inhibit the expression of a target gene, one of which is the administration of pre-formed antisense oligonucleotides, or short interfering RNA oligonucleotides (siRNA). However, these small molecules are easily hydrolyzed by the nucleases present in the cell, which reduces the half-life of their therapeutic effects. This problem could be overcome by generating an antisense RNA or a hairpin siRNA coded by a gene under the control of a promoter suitable for the long-term generation of the therapeutic molecules by the individual itself.

We present below four different gene therapeutic approaches in the treatment of hemochromatosis. The location of each action is shown in figure 2 .

\section{Inhibition of DMT-1 gene expression in intestinal cells. A general treatment approach}

There is compelling evidence indicating that DMT-1 is the main apical iron transporter. The microcytic anemia mutant mice, which carry a deleterious missense mutation in DMT-1, have a severe iron deficiency ( $\mathrm{Su}$ et al., 1998), indicating a main role for DMT1 in intestinal iron absorption. Similarly, while HFE knockout mice have a severe iron overload phenotype, double HFE/DMT1 knockout mice do not overload with iron (Levy et al., 2000). Thus, DMT-1 is likely to play a major role in intestinal iron uptake by $\mathrm{HH}$ patients. A possible therapeutic approach for the treatment of all hereditary hemochromatosis forms (independent of its etiology) is to reduce the expression of the apical DMT-1 transporter gene by the use of an antisense gene or a siRNA gene in the enterocyte, thus inhibiting iron uptake by the gut.

Two attempts have been reported to inhibit DMT-1 gene expression in intestinal epithelial Caco-2 cells, an appropriate model of polarized intestinal cell for the study of iron absorption (Meunier et al., 1995). In one of these studies, Bannon et al. (2003) established two clonal knockdown DMT-1 cell lines accomplished with a ribozyme against DMT-1 mRNA. These cells exhibited much lower levels of DMT$1 \mathrm{mRNA}$ and also displayed lower levels of apical iron uptake. In the other study, we generated an AAV viral vector carrying a short antisense gene against an internal region of DMT-1 mRNA and showed that 


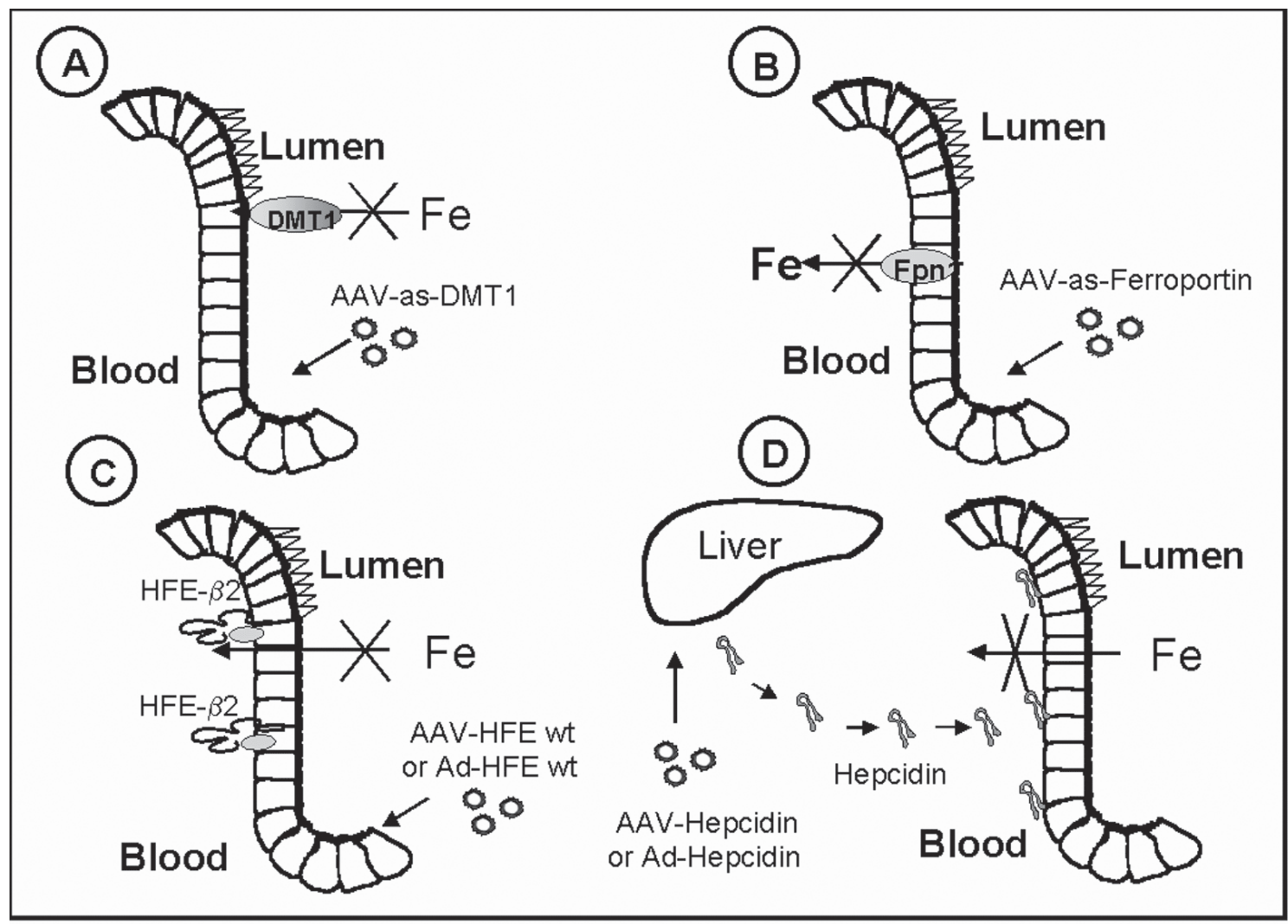

Figure 2: Proposed target for gene therapy approaches in hemochromatosis (targets are marked by X): A) Reduction of the apical DMT-1 transporter levels in enterocytes. B) Reduction of the basolateral ferroportin transporter levels in enterocytes. C) Overexpression of the wtHFE protein in enterocytes. D) Overexpression of the iron uptake inhibitory protein hepcidin generated by hepatocytes.

this treatment blocked DMT-1 gene expression and markedly inhibited apical iron uptake by these cells (Ezquer et al., 2004; 2005).

The divalent metal transporter DMT-1 recently has been shown to also transport copper ions (Arredondo et al., 2003) thus inhibition of DMT-1 gene expression may be of value in reducing liver injury in Wilson's disease, a condition in which copper export from cells is diminished.

\section{Inhibition of ferroportin gene expression in enterocytes}

Another target for the treatment of hemochromatosis is the inhibition of expression of the gene for the basolateral iron exporter ferroportin in intestinal cells.
The ferroportin gene is overexpressed in the enterocytes of hemochromatosis patients, and its inhibition should lead to a reduction of the export of iron from the intestinal lumen to the blood. In this case, absorbed iron would accumulate inside the enterocyte. Additionally, the accumulation of iron should lead to a reduction in the expression of the apical DMT-1 transporter gene by the IRE/IRP mechanism, producing a dual inhibitory effect. Further, any accumulated iron would be lost into the intestinal lumen by the normal slough of enterocytes.

Recently Galli et al. (2004) evaluated the effect of the posttranscriptional ferroportin gene silencing in human macrophages by using small interfering RNAs (siRNA). In macrophages, 
ferroportin is involved in the release of iron to the circulation for its reutilization. In this report, the siRNA treatment generated a reduction of $65-95 \%$ of the ferroportin mRNA leading to a marked iron loading of the cells.

We have reproduced this inhibitory effect in intestinal epithelial Caco-2 cells using an adeno-associated viral vector coding an antisense gene against an internal region of the ferroportin mRNA. In these experiments, we observed a marked decrease in iron efflux from the Caco-2 cells and an increase in the intracellular iron pool, indicating that the ferroportin inhibition could have therapeutic potential (Ezquer et al., unpublished).

\section{Expression of the wild-type HFE gene in enterocytes}

HFE is highly abundant in the crypts of the small intestine (Parkkila et al., 1997). The HFE knockout mice exhibit profound abnormalities in iron homeostasis, with high transferrin saturation and marked accumulation of iron in the liver, symptoms strikingly similar to those observed in patients with homozygous HH (Zhou et al., 1998). This observation clearly suggests that an exogenous, wild-type HFE protein in intestinal cells should decrease the symptoms of this disease.

Arredondo et al. (2001) overexpressed the wild-type HFE protein in intestinal epithelial Caco-2 cells and found a marked reduction of apical iron uptake with the consequent decrease in intracellular iron content, despite an increase in DMT-1 mass. These results suggested that HFE is a negative modulator of DMT-1 activity, although the mechanism is not known. In the nonpolarized HeLa cell line, HFE overexpression reduces by $33 \%$ the amount of iron taken up by endocytosis of transferrin (Roy et al., 1999), also indicating a role of HFE in iron regulation through the transferrin-mediated pathway of iron uptake. The transferrin-mediated uptake of iron is the normal mechanism of iron uptake by non-intestinal cells .

In advanced cases of $\mathrm{HH}$ in which liver damage is evident, this approach also could be used to transduce the liver, thus protecting it from further iron accumulation damage.

\section{Gene delivery into enterocytes}

The potential target for the three treatments of $\mathrm{HH}$ indicated above is the duodenal stem cell. One effective way of transducing a therapeutic gene in intestinal cells from the luminal side is by oral administration of an AAV viral vector. The AAV is a human parvovirus carrying a small, single-stranded DNA genome. This vector is currently considered to be one of the most promising viral vector systems for gene therapy because of a unique combination of properties, including the lack of association with any human disease, which gives AAV one of the highest biosafety ratings among all gene transfer viral vectors (Carter and Samulski, 2000). This virus has the ability to induce long-term gene expression because its recombinant genome establishes stable episomal forms and also may be integrated into the host genome (Monahan and Samulski, 2000). The AAV virus also is resistant to physiological temperatures and to extreme $\mathrm{pH}$ conditions (Berns et al., 1979), making it a suitable vector for oral administration.

Studies by During et al. (1998) showed that the oral administration of an AAV carrying a therapeutic gene maintained a stable expression of the transgene in the rat intestine for at least six months. Since the turnover of the enterocyte is 3-5 days, such a protracted expression indicates that stem cells within the crypts also were transduced by the AAV. Recent studies have demonstrated that transfection of a reporter gene into intestinal cells also can be accomplished by oral administration of plasmids encapsulated in chitosan, a polymer of D-glucosamine carrying positive charges, which protects and facilitates the incorporation of the DNA to the intestinal cells (Chen et al., 2004). It also is possible to transduce enterocytes from the basolateral side, and adenoviral vectors would be the preferred vectors if this route were chosen. 


\section{Overexpression of the iron regulatory peptide hepcidin in the liver}

The recently identified peptide hepcidin is a key regulator of iron metabolism. It is synthesized predominantly in the liver and secreted as a peptide of 20-25 amino acids (Krause et al., 2000; Park et al., 2001; Pigeon et al., 2001). Hepcidin mRNA is clearly induced by dietary or parenteral iron overload (Ganz, 2003). Hepcidin-deficient mice accumulate iron in parenchymal cells due to increased intestinal absorption and impaired retention of iron by reticuloendothelial macrophages (Nicolas et al., 2001). The mechanism by which hepcidin regulates iron absorption is not well known. In rats, hepcidin inhibits luminal iron uptake (Laftah et al., 2004) and induces ferroportin 1 down-regulation (Yeh et al., 2004), while in HeLa cells, hepcidin induces the internalization and degradation of ferroportin 1 (Nemeth et al., 2004). Thus, hepcidin seems to be a negative modulator of iron release both from reticuloendothelial macrophages and from the enterocytes that mediate intestinal absorption of iron.

Complete hepcidin deficiency resulting in juvenile hemochromatosis appears to be uncommon (Roetto et al., 2003). However, low hepcidin mRNA levels in HFE knockout mice (Ahmad et al., 2002) and in patients with HFE-related hemochromatosis (Ahmad et al., 2002; Bridle et al., 2003) suggest that partial hepcidin deficiency may contribute to iron overload in the most common form of $\mathrm{HH}$, indicating that it should be possible to treat $\mathrm{HH}$ by overexpressing the iron regulatory hormone hepcidin in the liver (or in other cells) of $\mathrm{HH}$ patients. This hypothesis is supported strongly by the work of Weinstein et al. (2002). These authors analyzed resected tumors from two patients with large hepatic adenomas and severe iron-refractory microcytic anemia. In this clinical syndrome, resection of the tumors fully reversed the hematological abnormalities. In this work, it was demonstrated that the tumors autonomously overexpressed hepcidin mRNA, and the authors hypothesize that higher levels of hepcidin were the cause of the observed anemia.
In another study, Nicolas et al. (2003) crossed mice that overexpressed hepcidin with mice that were $h f e^{-/-}$deficient; the mouse model of hereditary hemochromatosis. They observed that the overexpression of the hepcidin transgene totally prevented iron overload in the liver of the transgenic $h f e^{-/}$ deficient mice, despite the absence of the HFE protein. In this way, it can be argued that hepcidin gene therapy could benefits individuals with $\mathrm{HH}$ by preventing iron overload and its complications. In this case, both third-generation adenoviral vectors, as well as adeno-associated vectors, could be the carriers of the hepcidin gene.

ADVANCES IN THE GENERATION OF ADENOVIRAL VECTORS FOR GENE THERAPY

In addition to adeno-associated vectors, adenoviral vectors are presently among the most prominent candidates for practical and safe applications in gene therapy. Reviews addressing the synthesis and delivery of adeno-associated vectors have been published recently (Buning et al., 2004; Gonin et al., 2004; Mandel et al., 2004) and therefore will not be covered here. Firstand second-generation (with several genetic improvements) adenoviral vectors have been used but they still present problems in terms of their clinical application.

Recently developed, third-generation helper-dependant (or "gutless") adenovirus vectors, which have been completely stripped of the sequences coding for the viral proteins, have almost totally reduced immunogenicity and hence appear ideal for the successful application of gene therapy technology. We have recently carried out work on the rational design, production and purification of adenoviral vectors (Manosalva et al., 2002; Andrews et al., 2003; Zúñiga et al., 2004). To produce adenovirus, complementary cells are needed. HEK 293 cells are adapted for this task because they contain the E1 essential replicative region of the adenoviral genome (Nadeau et al., 2000b; Nadeau et al., 2001). Currently, three limitations must be overcome before gene therapy technology is established, these are: safety, 
immunogenicity, and gene packaging capacity. One of these problems, immunogenicity, is being solved by the third-generation adenovirus mentioned above, which does not contain the replicative sequence of the virus. It is of note that some serotypes of adenoviruses, such as adenovirus 41 , are typically enteroviruses and are found in $17 \%$ of cases of infant diarrhea, thus indicating that such serotypes can resist the stringent conditions of the gastrointestinal tract (Croyle et al, 1998).

Once the problems mentioned above are solved, there will be a great demand for clinical-grade, viral vector stocks. To produce commercial quantities of adenoviral vectors, high-density cell cultures are required. Also, the adenovirus produced must be purified from residual cell debris and serum proteins before a clinical grade viral stock is obtained. To optimize the adenoviral vector production process, culture conditions must be controlled, so the minimum possible elements go into the culture media. To obtain maximum cell and virus yield from the minimum possible conditions, Flux Balance Analysis and Phenotypic Phase Plane analysis are powerful tools. We have used these tools to optimize vector production (Zúñiga et al., 2004). These were applied to the HEK 293 central metabolism in a stechiometric model consisting of 38 equations and two principal growth conditions: biomass growth and viral replication. The model equations include the TCA cycle, Glycolysis, Amino Acid Metabolism, Biomass Growth and Viral Replication. This is the first time that an equation for virus production has been included in such a model. Previous models (Nadeau et al., 2000a; Nadeau et al., 2000b; Nadeau et al., 2001) include complete equations for the central metabolism, taking into consideration waste products, such as urea and membrane elements, but not a virus production equation. In our model, some products, like membrane elements and waste, were not considered because they added to the condition number; instead, they were replaced with one biomass production equation, which the former models did not include. The model is of great help for efficient vector production as it shows that TCA cycle fluxes are generally twice as high in virus production as in cell metabolism. Glycolytic fluxes are $20 \%$ higher during normal cell metabolism than in virus-producing cells. An investigation was carried out to show flexibility of biomass and virus production if culture conditions, such as substrate concentrations, change. Virus metabolism was more sensitive to changes in culture conditions. A purification stage is required once the culture conditions are optimized. This would complete the necessary steps to obtain large quantities of clinical-grade adenoviral vectors. The engineering challenges presented by the purification and efficient production of adenovirus vectors on a relatively large scale have been tackled (Andrews et al., 2003). These studies include carrying out the production of the vectors in suspension cultures by adapting the HEK 293 cells, scalable methods of cell lysis and membrane separation. For purification of the adenoviral vectors, we have investigated successfully and established the conditions for the use of chromatography and of aqueous two-phase (polymer/salt) systems (Andrews et al., 2003). Improved viral vector generation will be of great value in a number of applications, including hemochromatosis.

\section{CONCLUSIONS}

Hereditary hemochromatosis is the most prevalent genetic disease in Caucasian populations, the only accepted treatment being a weekly phlebotomy therapy with removal of 450-500 $\mathrm{ml}$ of blood, affecting quality of life and leading to neutropenia and to recurrent infections. In this work, we postulate four specific targets that could be altered by gene therapy technology to greatly reduce the accumulation of iron in hemochromatosis patients. These targets should be first evaluated in the mouse model of hereditary hemochromatosis to lead, in the near future, to a gene therapy approach that could replace the medieval technique of phlebotomy. 


\section{ACKNOWLEDGEMENTS}

The studies of gene therapy for hemochromatosis described here were supported by ICM-P99-031F, FONDECYT 1040448 and MECESUP P-12. We thank Dr. Amalia Sapag for helpful discussions of this work.

\section{REFERENCES}

ADAMS PC, KERTESZ AE, VALBERG LS (1991) Clinical presentation of hemochromatosis: A changing scene. Am J Med 90: 445-449

AHMAD KA, AHMANN JR, MIGAS MC, WAHEED A, BRITTON RS, BACON BR, SLY WS, FLEMING RE (2002) Decreased liver hepcidin expression in the Hfe knockout mouse. Blood Cells Mol Dis 29: 361-366

AGUIRRE P, MENA N, TAPIA V, ARREDONDO M, NÚÑEZ MT (2005) Iron homeostasis in neuronal cells: A role for IREG1. BMC Neurosci 6: 3 (online).

ANDREWS BA, MANOSALVA H, ISRAEL Y, ASENJO JA (2003) Challenges in the production and purification of first and third generation adenovirus vectors for gene therapy. 12th International Conference on Biopartitioning and Purification, Vancouver, British Columbia, Canada

ANDREWS NC (1999) Disorders of iron metabolism. N Engl J Med. 341: 1986-1995

ARREDONDO M, MUÑOZ P, MURA CV, NÚÑEZ MT (2001) HFE inhibits apical iron uptake by intestinal epithelial (Caco-2) cells. FASEB J 15: 1276-1278

ARREDONDO M, MUÑOZ P, MURA CV, NÚÑEZ MT (2003) DMT1, a physiologically relevant apical $\mathrm{Cu} 1+$ transporter of intestinal cells. Am J Physiol Cell Physiol 284: C1525-15230

BACON BR, POWELL LW, ADAMS PC, KRESINA TF, HOOFNAGLE JH (1999) Molecular medicine and hemochromatosis: At the crossroads. Gastroenterology 116: 193-207

BANNON DI, ABOUNADER R, LEES PS, BRESSLER JP (2003) Effect of DMT1 knockdown on iron, cadmium, and lead uptake in Caco-2 cells. Am J Physiol Cell Physiol 284: C44-50

BASTIN JM, JONES M, OCALLAGHAN CA, SCHIMANSKI L, MASON DY, TOWNSEND AR (1998) Kupffer cell staining by an HFE-specific monoclonal antibody: Implications for hereditary haemochromatosis. Br J Haematol 103: 931-941

BERNS KI, HAUSWIRTH WW (1979) Adeno-associated viruses. Adv Virus Res 25: 407-449

BRIDLE KR, FRAZER DM, WILKINS SJ, DIXON JL, PURDIE DM, CRAWFORD DH, SUBRAMANIAM VN, POWELL LW, ANDERSON GJ, RAMM GA (2003) Disrupted hepcidin regulation in HFE-associated haemochromatosis and the liver as a regulator of body iron homoeostasis. Lancet 361: 669-673

BRITTENHAM GM, WEISS G, BRISSOT P, LAINE F, GUILLYGOMARCH A, GUYADER D, MOIRAND R, DEUGNIER Y (2000) Clinical consequences of new insights in the pathophysiology of disorders of iron and heme metabolism. Hemotology 2000: 39-50

BUNING H, BRAUN-FALCO M, HALLEK M (2004) Progress in the use of adeno-associated viral vectors for gene therapy. Cells Tissues Organs 177: 139-150
CAMASCHELLA C, ROETTO A, CALI A, DE GOBBI M, GAROZZO G, CARELLA M, MAJORANO N, TOTARO A, GASPARINI P (2000) The gene TFR2 is mutated in a new type of haemochromatosis mapping to $7 q 22$. Nat Genet 25: 14-15

CARTER PJ, SAMULSKI RJ (2000) Adeno-associated viral vectors as gene delivery vehicles. Int J Mol Med 6: 17-27

CHEN J, YANG WL, LI G, QIAN J, XUE JL, FU SK, LU DR (2004) Transfection of mEpo gene to intestinal epithelium in vivo mediated by oral delivery of chitosan-DNA nanoparticles. World J Gastroenterol 10(1): 112-116

CROYLE MA, STONE M, AMIDON GL, ROESSLER BJ (1998) In vitro and in vivo assessment of adenovirus 41 as a vector for gene delivery to the intestine. Gene Ther 5: $645-654$

DAVIES PS, ENNS CA (2004) Expression of the hereditary hemochromatosis protein HFE increases ferritin levels by inhibiting iron export in HT29 cells. J Biol Chem 279: 25085-25092

DONOVAN A, BROWNLIE A, ZHOU Y, SHEPARD J, PRATT SJ, MOYNIHAN J, PAW BH, DREJER A, BARUT B, ZAPATA A, LAW TC, BRUGNARA C, LUX SE, PINKUS GS, PINKUS JL, KINGSLEY PD, PALIS J, FLEMING MD, ANDREWS NC, ZON LI (2000) Positional cloning of zebrafish ferroportin 1 identifies a conserved vertebrate iron exporter. Nature 403: 776-781

DURING MJ, XU R, YOUNG D, KAPLITT MG, SHERWIN RS, LEONE P (1998) Peroral gene therapy of lactose intolerance using an adeno-associated virus vector. Nat Med 4: 1131-1135

ELISMA F, JUMARIE C (2001) Evidence for cadmium uptake through Nramp2: Metal speciation studies with Caco-2 cells. Biochem Biophys Res Commun 285: 662-668

EZQUER F, NÚÑEZ M T, ISRAEL Y (2004) Hemochromatosis: Antisense gene against the DMT-1 transporter inhibits iron uptake in human intestinal cells and shows RNAi and antisense effects. Biol Res 37 (Supplement A): R89

EZQUER F, NÚÑEZ M T, ISRAEL Y (2005) Antisense gene delivered by an adenoassociated viral vector inhibits iron uptake in human intestinal cells: Potential application in hemochromatosis. Biochem Pharmacol 69: $1559-1566$

FEDER JN, GNIRKE A, THOMAS W, TSUCHIHASHI Z, RUDDY DA, BASAVA A, DORMISHIAN F, DOMINGO R JR, ELLIS MC, FULLAN A, HINTON LM, JONES NL, KIMMEL BE, KRONMAL GS, LAUER P, LEE VK, LOEB DB, MAPA FA, MCCLELLAND E, MEYER NC, MINTIER GA, MOELLER N, MOORE T, MORIKANG E, WOLFF RK (1996) A novel MHC class I-like gene is mutated in patients with hereditary haemochromatosis. Nat Genet 13: 399-408

FEDER JN, TSUCHIHASHI Z, IRRINKI A, LEE VK, MAPA FA, MORIKANG E, PRASS CE, STARNES SM, WOLFF RK, PARKKILA S, SLY WS, SCHATZMAN RC (1997) The hemochromatosis founder mutation in HLA-H disrupts beta2microglobulin interaction and cell surface expression. J Biol Chem 272: 14025-14028

FEDER JN, PENNY DM, IRRINKI A, LEE VK, LEBRON JA, WATSON N, TSUCHIHASHI Z, SIGAL E, BJORKMAN PJ, SCHATZMAN RC (1998) The hemochromatosis gene product complexes with the transferrin receptor and lowers its affinity for ligand binding. Proc Natl Acad Sci USA 95: 1472-1477 
FLEMING MD, TRENOR CC 3RD, SU MA, FOERNZLER D, BEIER DR, DIETRICH WF, ANDREWS NC (1997) Microcytic anaemia mice have a mutation in Nramp2, a candidate iron transporter gene. Nature Genetics 16: 383-386

FLEMING MD, ROMANO MA, SU MA, GARRICK LM, GARRICK MD, ANDREWS NC (1998) Nramp2 is mutated in the anemic Belgrade (b) rat: Evidence of a role for Nramp2 in endosomal iron transport. Proc Natl Acad Sci USA 95: 1148-1153

FLEMING RE, MIGAS MC, HOLDEN CC, WAHEED A, BRITTON RS, TOMATSU S, BACON BR, SLY WS (2000) Transferrin receptor 2: Continued expression in mouse liver in the face of iron overload and in hereditary hemochromatosis. Proc Natl Acad Sci USA 97: 2214-2219

FLEMING RE, BRITTON RS, WAHEED A, SLY WS, BACON BR (2004) Pathogenesis of hereditary hemochromatosis. Clin Liver Dis 8: 755-773

FORBES JR, GROS P (2003) Iron, manganese, and cobalt transport by Nramp1 (Slc11a1) and Nramp2 (Slc11a2) expressed at the plasma membrane. Blood 102: 18841892

GALLI A, BERGAMASCHI G, RECALDE H, BIASIOTTO G, SANTAMBROGIO P, BOGGI S, LEVI S, AROSIO P, CAZZOLA M (2004) Ferroportin gene silencing induces iron retention and enhances ferritin synthesis in human macrophages. Br J Haematol 127: 598-603

GANZ T (2003) Hepcidin, a key regulator of iron metabolism and mediator of anemia of inflammation. Blood 102: 783-788

GOCHEE PA, POWELL LW, CULLEN DJ, DU SART D, ROSSI E, OLYNYK JK (2002) population-based study of the biochemical and clinical expression of the H63D hemochromatosis mutation. Gastroenterology 122: 646-651

GONIN P, GAILLARD C (2004) Gene transfer vector biodistribution: Pivotal safety studies in clinical gene therapy development. Gene Ther. 11(Suppl 1): S98S108

GRIFFITHS WJ, COX TM (2003) Co-localization of the mammalian hemochromatosis gene product (HFE) and a newly identified transferrin receptor (TfR2) in intestinal tissue and cells. J Histochem Cytochem 51: 613-624

GROSS CN, IRRINKI A, FEDER JN, ENNS CA (1998) Co-trafficking of HFE, a nonclassical major histocompatibility complex class I protein, with the transferrin receptor implies a role in intracellular iron regulation. J Biol Chem 273: 22068-22074

GUNSHIN H, MACKENZIE B, BERGER UV, GUNSHIN Y, ROMERO MF, BORON WF, NUSSBERGER S, GOLLAN JL, HEDIGER MA (1997) Cloning and characterization of a mammalian proton-coupled metalion transporter. Nature 388: 482-488

HUBERT N, HENTZE MW (2002) Previously uncharacterized isoforms of divalent metal transporter (DMT)-1: Implications for regulation and cellular function. Proc Nat Acad Sci USA 99: 12345-12350

KAWABATA H, YANG R, HIRAMA T, VUONG PT, KAWANO S, GOMBART AF, KOEFFLER HP (1999) Molecular cloning of transferrin receptor 2. A new member of the transferrin receptor-like family. J Biol Chem 274: 20826-20832

KRAUSE A, NEITZ S, MAGERT HJ, SCHULZ A, FORSSMANN WG, SCHULZ-KNAPPE P, ADERMANN K (2000) LEAP-1, a novel highly disulfide-bonded human peptide, exhibits antimicrobial activity. FEBS Lett 480: 147-150
LAFTAH AH, RAMESH B, SIMPSON RJ, SOLANKY N, BAHRAM S, SCHUMANN K, DEBNAM ES, SRAI SK (2004) Effect of hepcidin on intestinal iron absorption in mice. Blood 103: 3940-3944

LEVY JE, MONTROSS LK, COHEN DE, FLEMING MD, ANDREWS NC (1999) The C282Y mutation causing hereditary hemochromatosis does not produce a null allele. Blood 94: 9-11

LEVY JE, MONTROSS LK, ANDREWS NC (2000) Genes that modify the hemochromatosis phenotype in mice. $\mathrm{J}$ Clin Invest 105: 1209-1216

LYNCH SR, SKIKNE BS, COOK JD (1989) Food iron absorption in idiopathic hemochromatosis. Blood 74 : 2187-2193

MANDEL RJ, BURGER C (2004) Clinical trials in neurological disorders using AAV vectors: Promises and challenges. Curr Opin Mol Ther 6: 482-490

MANOSALVA H, KARAHANIAN E, ISRAEL Y, ANDREWS BA, ASENJO JA (2002) Challenges in the design and production of first and third generation adenovirus vectors for gene therapy. $8^{\text {th }}$ International Conference on Cell Culture Engineering, Snowmass, Colorado, USA

MCKIE AT, MARCIANI P, ROLFS A, BRENNAN K, WEHR K, BARROW D, MIRET S, BOMFORD A, PETERS TJ, FARZANEH F, HEDIGER MA, HENTZE MW, SIMPSON RJ (2000) A novel duodenal ironregulated transporter, IREG1, implicated in the basolateral transfer of iron to the circulation. Mol Cell 5: 299-309

MCKIE AT, BARROW D, LATUNDE-DADA GO, ROLFS A, SAGER G, MUDALY E, MUDALY M, RICHARDSON C, BARLOW D, BOMFORD A, PETERS TJ, RAJA KB, SHIRALI S, HEDIGER MA, FARZANEH F, SIMPSON RJ (2001) An ironregulated ferric reductase associated with the absorption of dietary iron. Science 29: 1755-1759

MEUNIER V, BOURRIE M, BERGER Y, FABRE G (1995) The human intestinal epithelial cell line Caco-2; pharmacological and pharmacokinetic applications. Cell Biol Toxicol 11: 187-194

MONAHAN PE, SAMULSKI RJ (2000) Adeno-associated virus vectors for gene therapy: more pros than cons? Mol Med Today 6: 433-440

MONTOSI G, DONOVAN A, TOTARO A, GARUTI C, PIGNATTI E, CASSANELLI S, TRENOR CC, GASPARINI P, ANDREWS NC, PIETRANGELO A (2001) Autosomal-dominant hemochromatosis is associated with a mutation in the ferroportin (SLC11A3) gene. J Clin Invest 108: 619-623

NADEAU I, SABATIÉ J, KOEHL M, PERRIER M, KAMEN A (2000a) Human 293 cell metabolism in low glutamine-supplied culture: Interpretation of metabolic changes through metabolic flux analysis. Metabolic Engineering 2: 277-292

NADEAU I, JACOB D, PERRIER M, KAMEN A (2000b) 293SF Metabolic flux analysis during cell growth and infection with an adenoviral vector. Biotechnology Progress 16: 872-884

NADEAU I, GILBERT PA, JACOB D, PERRIER M, KAMEN A (2001) Low-protein medium affects the 293SF central metabolism during growth and infection with adenovirus. Biotechnology and Bioengineering 77: 93-104

NEMETH E, TUTTLE MS, POWELSON J, VAUGHN MB, DONOVAN A, WARD DM, GANZ T, KAPLAN J (2004) Hepcidin regulates cellular iron efflux by binding to ferroportin and inducing its internalization. Science 306: 2090-2093

NICOLÁS G, BENNOUN M, DEVAUX I, BEAUMONT C, GRANDCHAMP B, KAHN A, VAULONT S (2001) 
Lack of hepcidin gene expression and severe tissue iron overload in upstream stimulatory factor 2 (USF2) knockout mice. Proc Natl Acad Sci USA 98: 8780-8785

NICOLÁS G, BENNOUN M, PORTEU A, MATIVET S, BEAUMONT C, GRANDCHAMP B, SIRITO M, SAWADOGO M, KAHN A, VAULONT S (2002) Severe iron deficiency anemia in transgenic mice expressing liver hepcidin. Proc Natl Acad Sci USA 99: 4596-4601

NICOLAS G, VIATTE L, LOU DQ, BENNOUN M, BEAUMONT C, KAHN A, ANDREWS NC, VAULONT S (2003) Constitutive hepcidin expression prevents iron overload in a mouse model of hemochromatosis. Nat Genet 34: 97-101

NIEDERAU $C$, FISCHER $R$, SONNENBERG A, STREMMEL W, TRAMPISCH HJ, STROHMEYER G (1985) Survival and causes of death in cirrhotic and in noncirrhotic patients with primary hemochromatosis. $\mathrm{N}$ Engl J Med 313: 1256-1262

NJAJOU OT, VAESSEN N, JOOSSE M, BERGHUIS B, VAN DONGEN JW, BREUNING MH, SNIJDERS PJ, RUTTEN WP, SANDKUIJL LA, OOSTRA BA, VAN DUIJN CM, HEUTINK P (2001) A mutation in SLC11A3 is associated with autosomal dominant hemochromatosis. Nat Genet 28: 213-214

OATES PS, JEFFREY GP, BASCLAIN KA, THOMAS C, MORGAN EH (2000) Iron excretion in ironoverloaded rats following the change from an ironloaded to an iron-deficient diet. J Gastroenterol Hepatol 15: 665-674

OLIVI L, SISK J, BRESSLER J (2001) Involvement of DMT1 in uptake of Cd in MDCK cells: Role of protein kinase C. Am J Physiol Cell Physiol 281: C793-800

PAPANIKOLAOU G, SAMUELS ME, LUDWIG EH, MACDONALD ML, FRANCHINI PL, DUBE MP, ANDRES L, MACFARLANE J, SAKELLAROPOULOS N, POLITOU M, NEMETH E, THOMPSON J, RISLER JK, ZABOROWSKA C, BABAKAIFF R, RADOMSKI CC, PAPE TD, DAVIDAS O, CHRISTAKIS J, BRISSOT P, LOCKITCH G, GANZ T, HAYDEN MR, GOLDBERG YP (2004) Mutations in HFE2 cause iron overload in chromosome 1q-linked juvenile hemochromatosis. Nat Genet 36: 77-82

PARK CH, VALORE EV, WARING AJ, GANZ T (2001) Hepcidin, a urinary antimicrobial peptide synthesized in the liver. J Biol Chem 276: 7806-7810

PARKKILA S, WAHEED A, BRITTON RS, FEDER JN, TSUCHIHASHI Z, SCHATZMAN RC, BACON BR, SLY WS (1997) Immunohistochemistry of HLA-H, the protein defective in patients with hereditary hemochromatosis, reveals unique pattern of expression in gastrointestinal tract. Proc Natl Acad Sci USA 94: 2534-2539

PARKKILA S, WAHEED A, BRITTON RS, BACON BR, ZHOU XY, TOMATSU S, FLEMING RE, SLY WS (1997) Association of the transferrin receptor in human placenta with HFE, the protein defective in hereditary hemochromatosis. Proc Natl Acad Sci USA 94: 1319813202

PIGEON C, ILYIN G, COURSELAUD B, LEROYER P, TURLIN B, BRISSOT P, LOREAL O (2001) A new mouse liver-specific gene, encoding a protein homologous to human antimicrobial peptide hepcidin, is overexpressed during iron overload. J Biol Chem 276: 7811-7819
ROETTO A, PAPANIKOLAOU G, POLITOU M, ALBERTI F, GIRELLI D, CHRISTAKIS J, LOUKOPOULOS D, CAMASCHELLA C (2003) Mutant antimicrobial peptide hepcidin is associated with severe juvenile hemochromatosis. Nat Genet 33: 21-22

ROUAULT T, KLAUSNER R (1997) Regulation of iron metabolism in eukaryotes. Curr Top Cell Regul 35: 119

ROY CN, PENNY DM, FEDER JN, ENNS CA (1999) The hereditary hemochromatosis protein, HFE, specifically regulates transferrin-mediated iron uptake in HeLa cells. J Biol Chem 274: 9022-9028

SU MA, TRENOR CC, FLEMING JC, FLEMING MD, AND ANDREWS MC (1998) The G185R mutation disrupts function of iron transporter Nramp2. Blood 92: 2157-2163

TALLKVIST J, BOWLUS CL, LONNERDAL B (2001) DMT1 gene expression and cadmium absorption in human absorptive enterocytes. Toxicol Lett 122: 171177

VULPE CD, KUO YM, MURPHY TL, COWLEY L, ASKWITH C, LIBINA N, GITSCHIER J, ANDERSON GJ (1999) Hephaestin, a ceruloplasmin homologue implicated in intestinal iron transport, is defective in the sla mouse. Nat Genet 21: 195-199

WAHEED A, PARKKILA S, ZHOU XY, TOMATSU S, TSUCHIHASHI Z, FEDER JN, SCHATZMAN RC, BRITTON RS, BACON BR, SLY WS (1997) Hereditary hemochromatosis: Effects of C282Y and H63D mutations on association with beta2microglobulin, intracellular processing, and cell surface expression of the HFE protein in COS-7 cells. Proc Natl Acad Sci USA 94: 12384-12389

WEINSTEIN DA, ROY CN, FLEMING MD, LODA MF, WOLFSDORF JI, ANDREWS NC (2002) Inappropriate expression of hepcidin is associated with iron refractory anemia: Implications for the anemia of chronic disease. Blood 100: 3776-3781

WOJCIK JP, SPEECHLEY MR, KERTESZ AE, CHAKRABARTI S, ADAMS PC (2002) Natural history of $\mathrm{C} 282 \mathrm{Y}$ homozygotes for hemochromatosis. Can J Gastroenterol 16: 297-302

WOLF G, WESSLING-RESNICK M (1994) An integrinmobilferrin iron transport pathway in intestine and hematopoietic cells. Nutr Rev 52: 387-389

YEH KY, YEH M, GLASS J (2004) Hepcidin regulation of ferroportin 1 expression in the liver and intestine of the rat. Am J Physiol Gastrointest Liver Physiol 286: G385-394

ZOLLER H, THEURL I, KOCH RO, MCKIE AT, VOGEL W, WEISS G (2003) Duodenal cytochrome b and hephaestin expression in patients with iron deficiency and hemochromatosis. Gastroenterology 125: 746-754

ZHOU XY, TOMATSU S, FLEMING RE, PARKKILA S, WAHEED A, JIANG J, FEI Y, BRUNT EM, RUDDY DA, PRASS CE, SCHATZMAN RC, ONEILL R, BRITTON RS, BACON BR, SLY WS (1998) HFE gene knockout produces mouse model of hereditary hemochromatosis. Proc Natl Acad Sci USA 95: 24922497

ZÚÑIGA F, OLIVARES E, ASENJO JA, ANDREWS BA (2004) A metabolic model for the optimization of adenoviral vector production. $9^{\text {th }}$ International Conference on Cell Culture Engineering, Cancun, Mexico 